\title{
THE INFLUENCE OF THE ARABIC CONQUESTS ON A LINGUISTIC SITUATION IN SICILY
}

\author{
A INFLUENCIA DAS CONQUISTAS ÁRABES SOBRE UMA SITUAÇÃO \\ LINGUÍSTICA NA SICÍLIA
}

\author{
LA INFLUENCIA DE LAS CONQUISTAS ÁRABES EN UNA SITUACIÓN \\ LINGÜÍSTICA EN SICILIA
}

\author{
Aleksandra Yuryevna SEREDINA ${ }^{1}$ \\ Evelina Erkenovna MUKHAMETSHINA ${ }^{2}$ \\ Tatiana Evgenievna KALEGINA ${ }^{3}$
}

\begin{abstract}
This article is devoted to the study of the Italian language vocabulary, as well as its enrichment with Arabic borrowings under the influence of various historical events in the course of the historical development of the island of Sicily. The authors describe the main historical events that influenced the enrichment of the lexical composition of the Italian language with Arabic borrowings. The history of the Mediterranean is saturated with conflicts, meetings, migrations. For centuries, the region of southern Italy has been the center of various cultures and peoples, which greatly influenced the development of art and architecture as well as vocabulary of the people living in this territory. The purpose of the study is to describe and analyze the lexemes of Arabic origin present in the Italian language and Sicilian dialects. The lexemes are referred to "arabisms" that emerged during the period of Arab domination in the southern Italy and under the influence of the Arabic language. Within the scope the authors consider in detail the most important historical events that took place in certain periods in the region. In addition, the authors overview the semantic fields in which there are arabisms and the areas they are related, e.g. toponymy, material culture, agriculture, manufacturing, food, etc. Also, the geography of the region and the linguistic contacts are regarded due to the conquests of the Arabs in Sicily.
\end{abstract}

KEYWORDS: Linguistics. History. Language. Communication. Arabic language. Italian language.

RESUMO: Este artigo se dedica ao estudo do vocabulário da língua italiana, bem como ao seu enriquecimento com os empréstimos do árabe sob a influência de vários acontecimentos históricos ao longo do desenvolvimento histórico da ilha da Sicília. Os autores descrevem os principais acontecimentos históricos que influenciaram o enriquecimento da composição lexical da língua italiana com os empréstimos do árabe. A história do Mediterrâneo está saturada de conflitos, encontros, migrações. Durante séculos, a região do sul da Itália foi o

\footnotetext{
${ }^{1}$ Kazan Federal University (KPFU), Kazan - Russia. Professor of the Higher School of Foreign Languages and Translation Studies. ORCID: https://orcid.org/0000-0002-9941-1488. E-mail: sasha3163@yandex.ru

${ }^{2}$ Kazan Federal University (KPFU), Kazan - Russia. Senior Lecturer of the Higher School of Foreign Languages and Translation Studie. ORCID: https://orcid.org/0000-0002-0408-1579. E-mail: erkenovna@yahoo.com

${ }^{3}$ Kazan Federal University (KPFU), Kazan - Russia. Senior Lecturer of the Higher School of Foreign Languages and Translation Studie. ORCID: https:/orcid.org/0000-0001-6784-2657.E-mail: tatiana.kalegina@gmail.com
} 
centro de várias culturas e povos, o que influenciou muito o desenvolvimento da arte e da arquitetura, bem como o vocabulário das pessoas que vivem neste território. O objetivo do estudo é descrever e analisar os lexemas de origem árabe presentes na língua italiana e dialetos sicilianos. Os lexemas são chamados de "arabismos" que surgiram durante o período de dominação árabe no sul da Itália e sob a influência da língua árabe. Dentro do escopo os autores consideram detalhadamente os eventos históricos mais importantes que ocorreram em determinados períodos na região. Além disso, os autores apresentam uma visão geral dos campos semânticos nos quais existem arabismos e as áreas com as quais estão relacionados, por exemplo, toponímia, cultura material, agricultura, manufatura, alimentação etc. Também a geografia da região e os contatos linguísticos são considerados devido às conquistas dos árabes na Sicília.

PALAVRAS-CHAVE: Linguística. História. Linguagem. Idioma árabe. Língua italiana.

RESUMEN: Este artículo está dedicado al estudio del vocabulario de la lengua italiana, así como a su enriquecimiento con préstamos árabes bajo la influencia de varios eventos históricos en el curso del desarrollo histórico de la isla de Sicilia. Los autores describen los principales acontecimientos históricos que influyeron en el enriquecimiento de la composición léxica de la lengua italiana con préstamos árabes. La historia del Mediterráneo está saturada de conflictos, encuentros, migraciones. Durante siglos, la región del sur de Italia ha sido el centro de diversas culturas y pueblos, lo que influyó mucho en el desarrollo del arte y la arquitectura, así como en el vocabulario de las personas que viven en este territorio. El propósito del estudio es describir y analizar los lexemas de origen árabe presentes en la lengua italiana y los dialectos sicilianos. Los lexemas se denominan "arabismos" que surgieron durante el periodo de dominación árabe en el sur de Italia y bajo la influencia de la lengua árabe. Dentro del alcance los autores consideran en detalle los hechos históricos más importantes ocurridos en determinados períodos en la región. Además, los autores revisan los campos semánticos en los que hay arabismos y las áreas con las que están relacionados, p. Ej. toponimia, cultura material, agricultura, manufactura, alimentación, etc. También se considera la geografía de la región y los contactos lingüísticos debido a las conquistas de los árabes en Sicilia.

PALABRAS CLAVE: Lingüística. Historia. Lengua. Comunicación. Lengua árabe. Lengua italiana.

\section{Introduction}

The Southern Italy, Sicily in particular, has always been a land contested by the major powers, creating a history of the various dominations that have occurred from time to time. Thus, this territory was influenced by different cultures - from the tyrants of the Greek colonies to the Romans, then the Barbarians, Byzantines, Arabs, Normans, Suebian monarchs, Angevins, Aragonese, the Spanish Viceroys, the Bourbons who were the last rulers to give way to the dynasty of Savoy. The research work examines the traces and the influence of the Arabic conquests on Italian culture and language. 
The Arabic conquest of Sicily officially started in the 827 AD. Before, there were numerous unsuccessful raids as far back as 652, but rather attempts to conquer Sicily. However, the final expedition was carried out when the Byzantine rebel Euphemius called the arabs to help him. The conquest was hard; Palermo was conquered in 831, Messina in 843, helped by the Neapolitan troops (JENHANI, 2010, p. 112-113). Enna, which they called the Kasr Janna was taken in 859. The last to surrender were Syracuse in 878, Catania in 900 and Taormina in 902, and finally the occupation was completed with the fall of Rometta in the Strait of Messina in 965. The Arabic shipping had been guided by a lawyer Asad Ibn Furàt (D’AGOSTINO, 2013, p. 19).

During the Arab domination in Sicily, there was no a unite kingdom, but many small lordships directed by Kadi. Then the Arabs divided the island into large administrative districts; the Val di Mazara, which included the central west, the Val Demone, which included the northeastern part and the Val di Noto, the southern part. Sicily was the first province of the state Aghlabide, but after the fall of the dynasty passed to the dependence of the Fatimids of Egypt. By the year 960 Sicily became the hereditary principality of the Kalbiti dynasty (948-1040), under which it reached its maximum splendor (CUCINOTA, 1996, p. 49).

\section{Methods}

In order to conduct the study of the influence of the Arabic conquests on a linguistic situation in Sicily the following research methods have been used: the study of scientific literature, Internet resources, linguistic method, theoretical and practical analysis, audit experiment, electroacoustic analysis, synthesis of the obtained data.

For comparative and deeper comprehension, a range of the research findings have been under study where we can have a scope into the issue of the dialect studies. In the work of Deputatova et al. (2019) we find a discussion over multi-level linguistic features of regional dialects.

\section{Results and discussion}

The conquest of Sicily enriched the history and culture of western Arabs. They created deep roots in the Sicilian civilization and give life to a new culture whose extraordinary influence can still be felt nowadays. After their arrival the Muslims maintained the original structure of the cities and the conquerors and local population lived in peaceful coexistence, 
except for the bloody conquests of Castrogiovanni and Taormina, when men, women and children were massacred.

Apart from these tragic episodes, the Arab conquest contributed to urban revival and the development of the western part of Sicily. The eastern side, on the other hand, preserved its original urban characteristics longer and Arab penetration remained marginal. We can say that at least until the year 902 the expression "Muslim Sicily" did not quite fit the bill. In fact, before then, cultural, religious and ethnic differences divided local population from the Arabs. The conquerors who settled in Sicily themselves came from different parts of Islam and local people too couldn't be considered Sicilians because they were from the Roman Mediterranean areas or from the Byzantine empire and they spoke Greek or Latin. As well as Christians and Muslims there were also Jews, who had lived in Sicily for centuries. As previously mentioned, the submission of the people to the new occupiers often came about through agreement. The Arabs gave them a say in how to live their lives, even though they wanted to integrate them into their social structures; they allowed them aman (security), so that the Christians were protected (ahl adh dhimma) and free to express their religion, keep their traditions and possessions in return for a personal tax, called giziah and a land tax, the kharag (MAURICI, 1995).

The linguistic situation in the Mediterranean area at the time of the Arabic invasion represented a substantial division between the territories inhabited by populations of grecofones and latinofones that found reflection in their communication. Subsequently, in the lands of the African domination, the Latin was gradually supplanted by Arabic (the hegemonic language and culture) and by the spoken Berber. The Neo-Latin survived in more restricted areas probably until the XV century and represented a language of a substrate for the Arab and Berber of north-western Africa and provides it with a significant lexical heritage (TAGLIAVINI, 1972, p. 173-175).

With the arrival of the Arabs in Spain and Sicily there is an agricultural revolution. As the ongoing processes of interaction between different cultures impose on cross-cultural communication, it also influenced on technical breakthrough as well (SABIROVA et al., 2019, p. 101-106). They were skilled hydraulic engineers: it is demonstrated by lifting machinery, collection systems, water supply networks and canalization above and below the ground. In Palermo and in the surrounding areas a series of underground canals for irrigation of the fields have been found, and this has allowed the cultivation of new plants. The biggest innovation made by the Arabs consists in the integration of technologies that can capture, distribute and use the water for crops. 
They also adorned the gardens of the courtyard with fruit trees and flowers: orange, lemon and pomegranate trees, anemones, roses, daffodils, lilac and jasmine. Naturally, this vocabulary layer is the first to be influenced. The Arabs have strongly influenced the alimentation by introducing vegetable plants, new foods and spices: eggplant, spinach, artichokes, cucumbers, oranges, lemons, pomegranate, dates, sugar and honey used as sweeteners; ginger, saffron, turmeric, various types of pepper, cinnamon, anise, and cumin (CAPONE, 2014, p. 168-169).

Sicily was used as a network of maritime trade; it becomes the hub of activities in the Mediterranean and rises to a dominant role. During the 200 years of their domination, the Arabs brought to the island the culture, the poetry, the arts, oriental studies and an outstanding architecture.

The depth of penetration in the culture and language of the Arabs is attested not only by the numerous archival documents written in Arabic, by many artistic works that are scattered throughout the Sicily, by the magnificent descriptions of Arabic travelers and geographers such as ibn Jubayr, or al-Idrīsī, but also, in a strictly linguistic point, by the spread of toponyms of Arabic origin (PELLEGRINI, 1972).

The Arabic heritage in the field of onomastics and toponymy is very rich. As the culture of the Arab invasions is widely spread and evident in the linguistic landscape, in the toponymic names on the island (KALEGINA; SEREDINA, 2017, p. 27-41). For example, there are numerous toponomastic syntagmas with rạ̣l "place" (Racalmuto, Regalbuto, Ragalna, Regaleali), with qal a "castle" (Calascibetta, Calatabiano, Calatafimi, Caltagirone, Caltavuturo, Caltanissetta), with jabal "mountain" (Mongibello, Gibellina, Gibilmanna, Gibilrossa), with alquantar "bridge" (Alcàntara), with marsa "port” (Marsala, Marzamemi).

In onomastic field we can consider the numerous names and surnames: Càfaro (ar. kāfir "infidel"), Salemi (ar. salāmī "pacific"), Macaluso (ar. maxlūṣ "freed"), Fragalà - ("joy of Allah"), Vadalà, Badalà ("servant of Allah"), Zappalà ("strong in Allah") (CARACAUSI, 1993). Onomastic research shows that the Arabic culture has deep roots in the historic reality of the Sicily.

The Arabic influence on Sicilian dialects is found in more than 300 words of considerable importance in communication, the greatest number of them belongs to the sphere of agriculture. This is comprehensible and clear because the saracens introduced into Sicily a modern irrigation system and new species of agricultural plants, which remain endemic on the island. 
Thus, among Arabic words penetrated and preserved in the Sicilian dialects there is a great number of those that relate to the irrigation of the citrus groves in the fields. Thus, favara d'acqua "impetuous and abundant water source" (ar. fawwara); gebbia "rectangular and circular tank for water to be used especially in periods of drought "(ar. gabiya); zappa d'acqua "measurement of water" (ar. sabba); naca "stagnant water" (ar. naq); bunaca "the place where you put the linen in to soak" (ar. bù[abù]naqa); saia "channel where the water for the irrigation of the earth runs" (ar. saqija); catusu "pipe for pipeline" (ar. qddùs); dogala "the strip of cultivated land along the river", "the land exposed to flooding" (ar. daghal); margiu "marsh", "stagnant water" (ar. marg); cubba "earth put on the springs of water" (ar. qubba).

With other forms there is a specific reference to the works and to agricultural tools: burgiu "quantity of piled straw, wheat, etc.," (ar. burg); galibbari "put fallow (sic. maisa) the earth" (ar. qalaba); marzeppa "mallet to beat the wheat" (ar. mirzaba); mazzara "wood molding tool" (ar. mi sara), zzotta "whip" (ar. sawt); zzàccanu "the place where you put the beasts", "pigsty" (ar. sakan).

Arabic penetrated into other areas of the language, as is demonstrated by the terminology that follows: marmànicu or smam-mànicu "weird", "foolish" (ar. marinara); zizzu "elegant, well-dressed" (ar. azi'z); mammaluccu "body", "stunned" (ar. mamluks); musuìuccu "a thin person" (ar. masluq); giufà "a fool and stupid person" (ar. djehà or djuhà); tamarri! " villain", "rough farmer" (ar. tammar "the merchant of dates"); arrusu, iarrusu "pederast" (ar. Arus "girlfriend", "spouse"); maumettumilia "phrase of Trapani, which repeats the oath of the Turks" (ar. muhammad maih " Muhammad good"); cai-ramata "large quantity" (ar. ghamar); musciaru "lattice of rods for drying the fruit or tomatoes" (ar. minsàr or mansdr); rrunkuni "corner" (ar. rukn); sciara "lava flow or lava soil in decomposition, typical of the Etna area" (ar. sa'ra + harrafh). Of course, we can always find a trace of Arabic domination in proverbs. (SHAMSUTDINOVA; MINGAZOVA; SABIROVA, 2017). There is a proverb "parlare arabo" (to speak Arabic) that means "to speak an unknown language".

Words of Arabic origin in Sicilian dialects are also present in many other semantic fields: legal terms: albaranu (ar. al-barā'a "kind of private writing"), cangemia "fee of barbers" (ar. hajjām), funnacu (ar. funduq "warehouse"); titles and professions: algoziru (ar. al-wazīr "vizier"), camalu (ar. ḥammāl "porter"); the terms of seamanship: carrack (ar. ḥarrāqa "ship"), cassaru (ar. qașr "castle on the deck of the galley").

Other words of the Arabic origin had much more expansive force that seemed to be important. There is, for example, a handful of Sicilian arabisms penetrated into Italian dialects (not only southern). It is the case of the word cubbàita that indicates a kind of jam. From Sicily, 
where in the forms cubbaita, cubbeta and cubbarda it referred and still refers to a nougat of sesame seeds or even walnuts and almonds, it then spread throughout the peninsula up to Liguria, and penetrated in the Italian language.

\section{Conclusions}

The influence of the Arabic language on the Sicilian spoken dialects is obvious. The population of the Sicilian Island, even that of the rural areas, preserve its social as well as linguistic traditions through times. Thus, it is studied that the people of the region took from Arabic only the elements that are linked to various areas of human's everyday life: the cultivation of fields, especially in the citrus orchards, the construction techniques and names of agricultural tools, food, onomastics, toponymy, etc. It is worth to resume that Arab conquests caused to Arabic words, so named "arabisms", appearance and further penetration into the Italian language.

ACKNOWLEDGEMENTS: The work is performed according to the Russian Government Program of Competitive Growth of Kazan Federal University.

\section{REFERENCES}

CAPONE, C. Gli arabi e europa medievale: il contributo culturale. Torino: Ananke, 2014.

CARACAUSI, G. Dizionario onomastico della sicilia. Repertorio storico-etimologico di nomi di famiglia e di luogo. Palermo: Centro di studi filologici e linguistici siciliani, 1993. v. 2.

CUCINOTA, G. Ieri e oggi Sicilia (history, culture, problemi). Pellegrini Cosenza-Italy, 1996.

D’AGOSTINO, G. La lunga marcia dell'islàm politico. Gangemi Editore, 2013.

DEPUTATOVA, N. A. et al. Extra-linguistic features of the southern dialect of american english in the novel of harper lee "go set a watchman". Journal of Educational and Social Research, v. 9, n. 3, p. 117-124, 2019.

JENHANI, H. Al-qayrawàn (attasis wa izdihàr). Sotepa Graphic-Tunis, 2010.

KALEGINA, T.; SEREDINA, A. French in the framework of the linguistic landscape of north africa. Modern Journal of Language Teachin Methods, v. 7, n. 9-11, p. 27-41, 2017.

MAURICI, F. Breve storia degli arabi in sicilia. Palermo: Flaccovio, 1995. 
MUKHAMETSHINA, E.; MOROZOVA, T.; SHIGAPOVA, F. Teaching arabic language via english. In: INTERNATIONAL TECHNOLOGY, EDUCATION AND DEVELOPMENT CONFERENCE, 14., 2020, Valencia. Proceedings [...]. Valencia, Spain: INTED2020, 2020. p. 6777-6780.

PELLEGRINI, G. B. Gli arabismi nelle lingue neolatine con speciale riguardo all'Italia. Brescia: Paideia, 1972. v. 2.

SABIROVA, D. R. et al. Comprehension of the english national character in building professional linguistic culture. Journal of Educational and Social Research, v. 9, n. 3, p. 101-106, 2019.

SHAMSUTDINOVA, E. K.; MINGAZOVA, N. G.; SABIROVA, D. R. Analysis of arabic, english and tatar animal proverbs with complex and compound sentence structure. The Turkish Online Journal of Design, Art and Communication, p. 1055-1061, 2017. Available: http://www.tojdac.org/tojdac/VOLUME7-

APRLSPCL_files/tojdac_v070ASE226.pdf. Access: 10 Dec. 2020.

TAGLIAVINI, C., Le origini delle lingue neolatine. Padova: Patron, 1972.

\section{How to reference this article}

SEREDINA, A. Y.; MUKHAMETSHINA, E. E.; KALEGINA, T. E. The influence of the arabic conquests on a linguistic situation in sicily. Rev. EntreLínguas, Araraquara, v. 7, n. esp. 3, e021058, Sep. 2021. e-ISSN: 2447-3529. DOI: https://doi.org/10.29051/el.v7iesp.3.15726

Submitted: $10 / 01 / 2021$

Required revisions: 20/03/2021

Approved: 23/06/2021

Published: 01/08/2021 